MISCELLANEA
GEOGRAPHICA

Vol. 13/2008

pp. 21-32

\author{
Piotr Sikorski \\ Warsaw University of Life Sciences - Department of Environmental Protection \\ e-mail: piotr_sikorski@sggw.pl \\ Karolina Jackowiak, Iwona Szumacher \\ University of Warsaw - Faculty of Geography and Regional Studies - Department of Geoecology \\ 00-927 Warsaw, Krakowskie Przedmieście 30 \\ e-mail: szumi@uw.edu.pl

\section{INTERDISCIPLINARY ENVIRONMENTAL STUDIES IN URBAN PARKS AS A BASIS FOR THEIR SUSTAINABLE MANAGEMENT}

\begin{abstract}
The goal of this paper is to present interdisciplinary environmental studies in urban park. Simple measures are proposed here for evaluating the status of vegetation and its habitat. When systematically applied, these measures could be a basis for sustainable management of the park greenery. Studies performed in Skaryszewski Park in Warsaw are as an example. Studies confirmed the assumption that simple and relatively cheap field and laboratory methods could be a good basis for recognising the status of plant habitats in parks.
\end{abstract}

Key words: urban park, Skaryszewski Park, interdisciplinary studies, sustainable management, monitoring

\title{
INTRODUCTION
}

Park conservation should be based on both cultural and natural aspects without discriminating any of the two (ICOMOS 1999). Management of the park greenery, in view of its sustainable development, requires thus interdisciplinary studies and protection of the whole complexicity (Olenderek et al. 1994). Vegetation is an important element in park structure which, in contrast with other elements, is 
subject to maturing, ageing and dying off. Changes in vegetation are determined by biotic and abiotic factors being sensitive to their modifications. Rational conservatory works and revalorization of vegetation, particularly in an old park, are possible providing sufficient information on the plant status and its changes. Complex inventory of vegetation based on principles described e.g. by Janecki and Sawczuk (1995) or Sikorski and Wysocki (2003) may bring valuable information on species diversity and, if carried regularly, on changes in vegetation. Environmental properties that affect vegetation status should be first of all monitored in a park. Such features include: soil fertility, concentration of pollutants, water relations and microclimate (Jim 1998, Kin-Che et al. 2005). The second group of monitored elements should encompass modifications of the status of single trees or small tree clusters measured with dendrometric or photometric methods (Borowski et al. 2005). Moreover, the dynamics of coppices and herbal vegetation should be measured with phytoindication methods (Hermy, Cornelis 2000, 2004, Bianco et al. 2003). Measurements and observations of plant health made with photointerpretation methods might be useful in large parks. Observations of biodiversity of various groups of living organisms also seem to be important (Hermy and Cornelis 2000, 2004).

Indicators for evaluating present status and possible changes should be individually fitted to local conditions in a park in order to identify potential stressors of plants and plant communities (Lookingbill et al. 2007). Early enough identification of habitat changes allows for applying appropriate countermeasures (Zipperer W. C., Zipperer C. E. 1992). Simple measures are proposed here for evaluating the status of vegetation and its habitat. When systematically applied, these measures could be a basis for sustainable management of the park greenery. Studies performed in Skaryszewski Park in Warsaw will serve as an example.

\section{STUDY AREA}

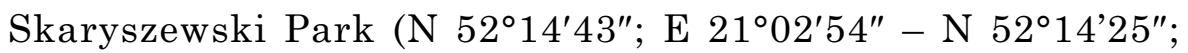
E $\left.21^{\circ} 03^{\prime} 44^{\prime \prime}\right)$ is the largest Warsaw park right of the Vistula River. It was established in 1905 on meadows of the Vistulian flood terrace. The park was designed as an urban park in the landscape style with features of landscape ring road gardens typical of the end of the XIX century and of Modernistic gardens of the XX century. It combines 
both free and geometric elements. Primarily the park area was flat, monotonous and not diversified. Franciszek Szanior (1853-1945), the park designer, adopted the area to park plans projecting artificial undulations and hills associated with an interesting complex of artificial water bodies. The first stage of earthworks consisted in draining and levelling of the Skaryszewska Meadow. Eastern part of the area was elevated in 1906. Elevations were also built near ponds and entrance gates. A year later first trees were planted there. Thanks to a low location it was easy to dig out four ponds of various sizes which were then connected with each other and with Lake Kamionkowskie through narrow channels. To ensure stable water level in the lake and to free it from water fluctuations in the Vistula a sluice with a bridge was built in Zieleniecka Avenue in the year 1911 (Kobendza 1930). During the war 1939-1945 the park was destroyed. The area was covered with bomb craters and trees were damaged by shells and bullets. In the year 1946 the craters were filled up, monuments were restored and 2 thousand spruce trees were planted.

\section{METHODS}

Surface formations, their permeability and retention capacity as well as soil fertility (air and water conditions, mineral nutrient content) were analysed to evaluate habitat quality. Moreover, microclimate of the park was analysed during seasonal meteorological measurement walks (temperature and humidity). Local climate is important not only for the role parks play in a town but also for plant growth (Jackowiak 2007).

Soil samples from the upper $(0-10 \mathrm{~cm})$ soil layer were taken from 12 sites in the park (Fig. 1) for further lab analyses which included: grain size structure (Casagrande's method modified by Pruszyński), instantaneous and actual bulk density $(\mathrm{Co})$, capillary porosity $(\mathrm{Pk})$, $\mathrm{pH}_{\mathrm{KCl}}$, $\mathrm{CaCO}_{3}$, sum of basic exchangeable cations ( $\mathrm{S}$ - Kappen's method), hydrolytic acidity (Hh - Kappen's method) and organic carbon (Tiurin's method). Based on obtained results the soil sorption capacity (T), percentage share of basic exchangeable cations in the sorption complex $(\% \mathrm{VS})$ and percentage share of hydrogen in the sorption complex $(\% \mathrm{VH})$ were calculated for each sample. A map of natural potential vegetation (Tüxen 1956) was made to evaluate habitat diversity. 
The map of topoclimates was made to evaluate the park's microclimate. The distinction of topoclimates was based on the distribution of active areas. Then, selected meteorological parameters were measured in 11 sampling sites (Fig. 1) with portable instruments. Air temperature and humidity were measured with thermohygrometer and wind velocity - with anemometer. The first two parameters were measured at two heights of $0.25 \mathrm{~m}$ and $1.5 \mathrm{~m}$ above ground and wind velocity - at a height of $1.5 \mathrm{~m}$. Wind direction, cloudiness, type of clouds and type of the ground in the site were recorded at the same time. Measurements were made in 9 sites within Skaryszewski Park and in 2 sites outside in a developed area on March 20, August 3 and December 9 of 2006. All measurements were performed at 8 a.m. and 4 p.m. during sunny, high-pressure weather.

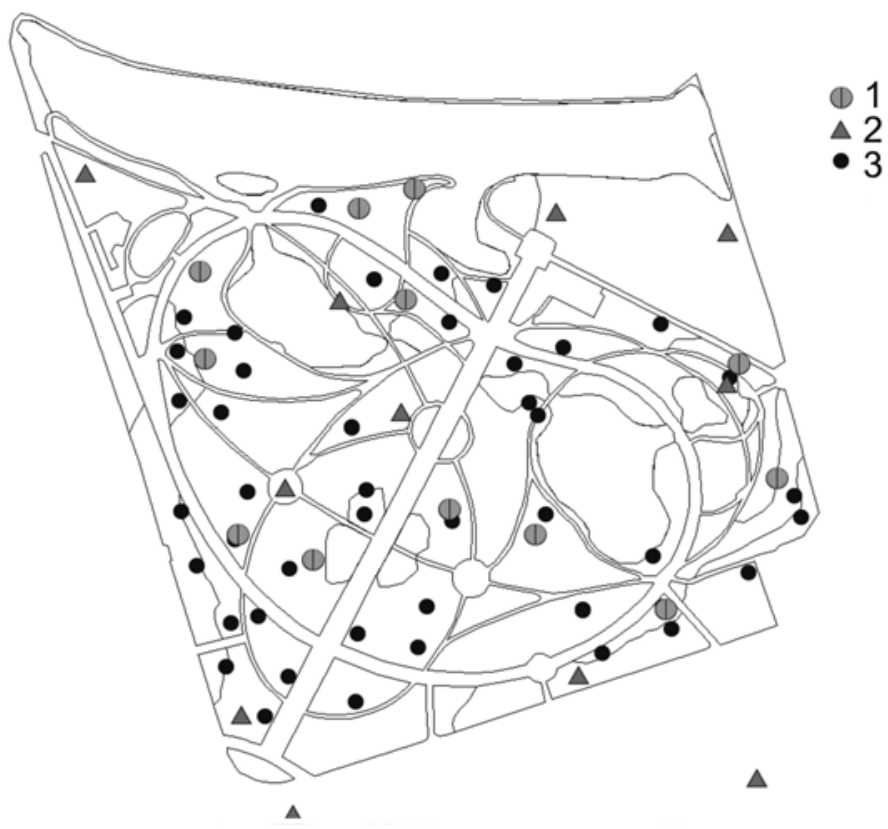

Fig. 1. Location of the sampling sites: 1 - habitat samples, 2 - meteorological samples, 3 - phytosociological releves

Forty four phytosociological releves were made in 2005 to evaluate vegetation status. They were situated in places representative for coppices and park lawns. Plots were located at least $10 \mathrm{~m}$ away from the 
border of plant community to exclude transitional effects and human impact associated with traffic routes.

Species diversity of spontaneous plants was calculated as the number of non-synanthropic species in samples. The index of synanthropization was estimated as percentage share of synanthropic species in samples (values in the range 0-1). Coverage of species from trampled communities of the order Plantaginetalia was adopted as an indicator of soil compaction.

Vegetation dynamics was analysed based on 14 plant species representing most important phytosociological classes of the highest frequency of occurrence. Data collected from 44 sites in 1966, 1985 and 2003-2006 were taken for analysis. Data from 1966 are known to be representative but no localization is given; later samples were collected from places shown in Fig. 1.

\section{RESULTS}

Studies in Skaryszewski Park confirmed the assumption that simple and relatively cheap field and laboratory methods could be a good basis for recognising the status of plant habitats in parks.

Medium to heavy alluvial soils are present in Skaryszewski Park. Their parent rock is Holocene formation composed of silt and river sands. Such soils are mainly found in the middle and northern part of the park. In south-western part of the park alluvial soils have been transformed by man and are now classified as anthropogenic soils. They contain rubble, mainly brick debris, originating from earthworks carried out when building Washington Roundabout, Washington Avenue and Zieleniecka Avenue. Human impact on anthropogenic soils resulted in changes of their morphological properties, some physical and chemical features and in an increase of heavy metal content in relation to crop soils. In general, habitat conditions are uniform and typical of dry ground forests Tilio-Carpinetum in the low, typical and tall variant.

Silt formations and light loam are characterised by medium permeability and high capillary water retention. Therefore, they can satisfy the water demands of plants. Capillary porosity of the humic layer in Skaryszewski Park is c. 50\%. It is particularly important during long droughts and in cases where atmospheric precipitation is the main source of water. Urban parks with shallow aquifers should 
permanently monitor ground water level. Long lasting ground water level fluctuations may lead to disappearance of many plant species sensitive to soil moisture.

\section{MEASURES OF ENVIRONMENTAL STATUS}

A feature of substratum affecting the character of vegetation is the degree of its compactness. It is estimated from measurements of actual bulk density. In Skaryszewski Park the bulk density varies from 0.9 to $1.3 \mathrm{~g} / \mathrm{cm}^{3}$. These values indicate favourable soil scarification which allows for the development of plant root system. Soil compactness might be indicated by the coverage of trampled species of the order Plantaginetalia. Fig. 2 shows significant share of trampled species in grassy lawns situated along the main avenue and around southern water reservoir.
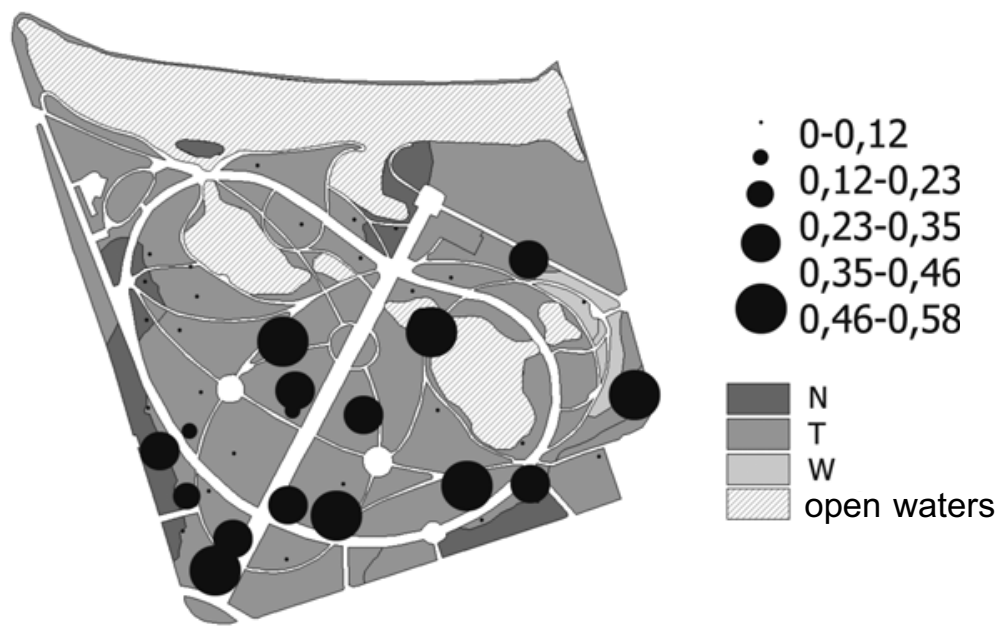

Fig. 2. Differentiation of trampling indices in Skaryszewski Park and the types of potential habitats: $\mathrm{N}$ - low subcontinental broadleaved forest, $\mathrm{T}$ - typical subcontinental broadleaved forest, $\mathrm{W}$ - tall subcontinental broadleaved forest

Changes in soil pH may affect species composition of the woody undergrowth and, to a less extent, of lawns. Soil pH in most parts of the studied area is slightly acidic for the benefit of plant growth. Acidic reaction can be found in places overgrown by coniferous trees. The least 
sum of basic cations in soils ( $\mathrm{S}=15.5 \mathrm{me} / 100 \mathrm{~g}$ ) and the saturation of the sorption complex with bases (\%VS up to $40 \%$ ) were found there. In other places S amounts up to $50 \mathrm{me} / 100 \mathrm{~g}$ and $\% \mathrm{VS}-$ c. $90 \%$.

Humus content in soils of studied area ranges from 3.2 to $6.8 \%$ being similar to that noted in the eighties of the XX century $(4.3 \%$ - Szczepanowska, 1984). The highest humus contents were found in samples taken from sites densely overgrown with shrubs and deciduous trees. High humus content in these places might be associated with plants producing large biomass. Soil samples collected from glades contained less humus - c. $3 \%$.

The share of synanthropic species (Fig. 3) in coppices and lawns expressed with the synanthropization index is a synthetic measure of transformations in vegetation. These disturbances may result from human impact in the site or from inappropriate nurturing. The index is not very useful for lawns where synanthropic species are eliminated by mowing. It is important in coppices where it reflects the mixing of upper layer of soil profile, excessive raking, destruction of humus layer and excessive removal of the tree canopy. Such situation can sometimes be maintained for many years since low mowing of abundant annual and two-year vegetation eliminates also slow dispersing forest and margin vegetation species.
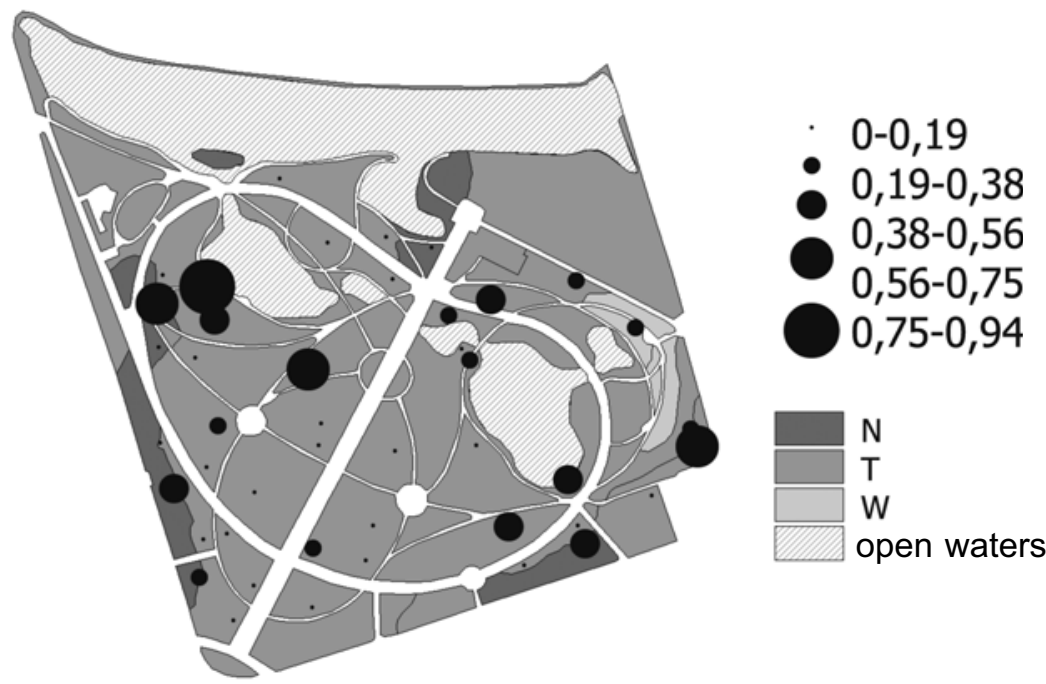

Fig. 3. Differentiation of the synanthropization indices in Skaryszewski Park 
A universal measure of the natural character of vegetation is species diversity of plants (Fig. 4) which, together with synanthropization indices, allows for identifying most valuable areas in the park. Coppices are remarkably diverse. The richest in species (c. 20 species in the undergrowth) are coppices near Lake Kamionkowskie near the main axis of the park. Other coppices are markedly poorer (c. 10 species). Great species richness in park lawns is usually associated with the trampled and synanthropic plant species.
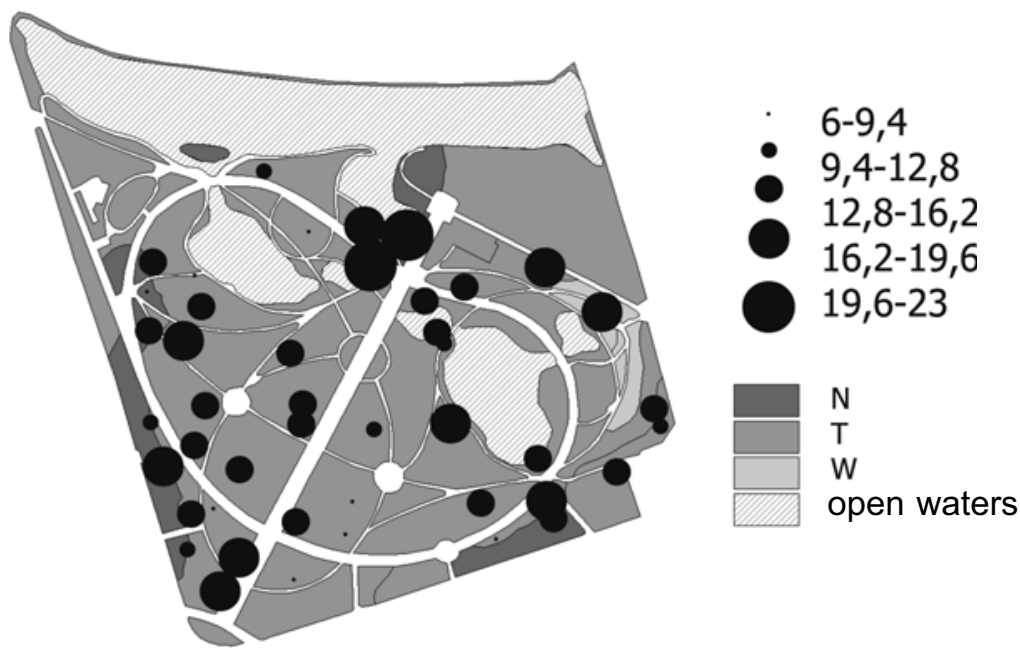

Fig. 4. Differentiation of the number of vascular plant species in the undergrowth of Skaryszewski Park

Results of the climatic transect studies and the map of topoclimates (Fig. 5) allowed for characterising the microclimate of particular areas. The characteristic may be summarised as follows:

1. Open lawns (glades) in the morning are characterised by the greatest vertical temperature variability among all other areas in the park. Temperature decreases with height over such areas. The differences in temperature between $0.25 \mathrm{~m}$ and $1.5 \mathrm{~m}$ above ground are from 0.5 to $1^{\circ} \mathrm{C}$. In the afternoon, however, there is temperature inversion i.e. temperature increases with height. Therefore, heat is lost most intensively from the ground in the afternoon and evening. Air is more humid over open lawns than over asphalt, concrete or gravel substratum but less humid than that over dense tree stand. 


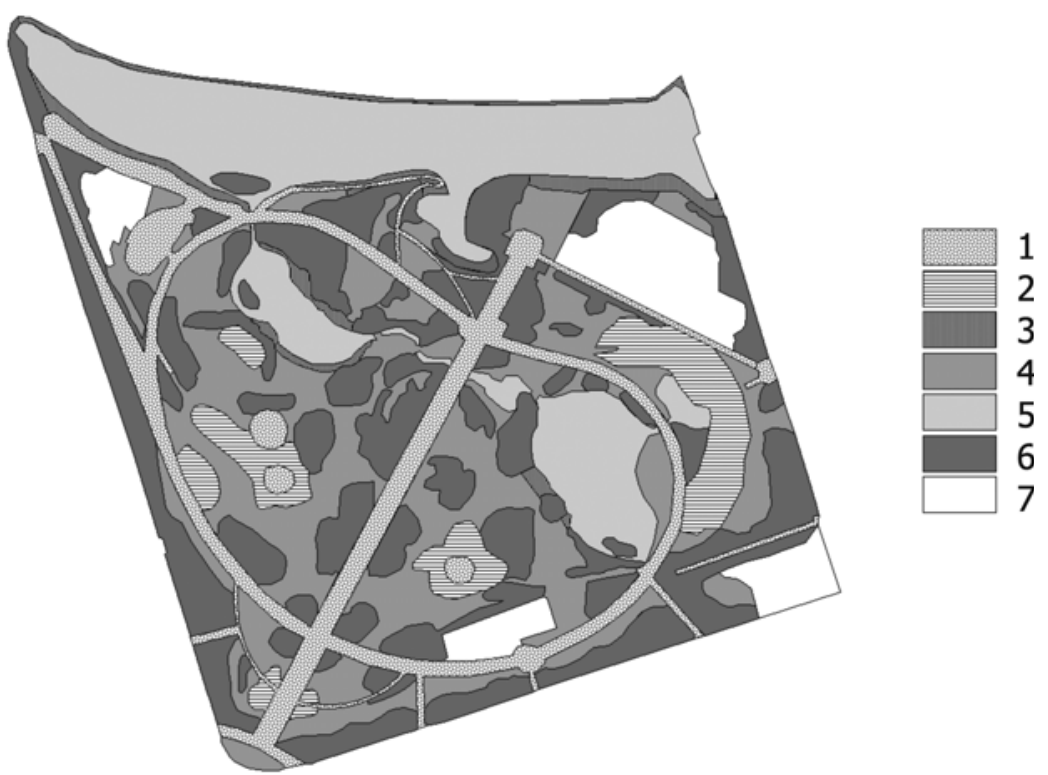

Fig. 5. Topoclimates in Skaryszewski Park: 1 - paved areas, 2 - coniferous coppices, 3 - areas neighbouring open waters, 4 - grassy areas, 5 - open waters, 6 - deciduous coppices, 7 - utility areas

2. In the morning, glades near water bodies have lowest temperatures which decrease with height. At the same time air humidity is the highest there. In the afternoon, air temperature in the vicinity of artificial water bodies is higher which reflects the warming effect of the latter. Water bodies increase relative humidity in their surrounding.

3. Areas densely overgrown with trees or shrubs show lower air temperature in the morning compared with those covered with asphalt, concrete or with open lawns. In the morning, air temperature under the tree canopy does not show vertical differentiation (temperature at $0.25 \mathrm{~m}$ and $1.5 \mathrm{~m}$ above ground does not differ). Relative air humidity among trees and deciduous shrubs is higher than over open lawns in both morning and afternoon.

4. Dry ground devoid of grass among coniferous trees (spruce) show slightly higher air temperatures than the areas among deciduous trees; air humidity is, however, lower there. Substratum of that type does not favour the formation of vertical gradients of air humidity. 
5. Areas covered with asphalt (alleys) and gravel plots are characterised by different thermal and humidity conditions than active areas. In both morning and afternoon there is higher temperature and lower moisture there. Asphalt and concrete substratum may warm the above-ground air layers. Substratum of that type looses heat accumulated during the daytime less intensively than the areas of open lawns. No vertical gradients of temperature or humidity are observed over these anthropogenic substrata.

Estimating topoclimates is of practical importance when assessing the frost risk. In Skaryszewski Park the areas particularly prone to frosts are open lawns, especially those near water bodies.

\section{THE DYNAMICS OF CHANGES}

Existing data on vegetation allow for interpreting changes that took place in the years 1966-2004 (Tab. 1). The changes involve the frequency of species found in undergrowth of coppices and in lawns. Species of annual or two years synanthropic plants like Chelidonium majus and Impatiens parviflora or perennials of large and slowly regrowing leaves like Arctium lappa retreated as a result of long lasting nurturing. The coverage of synanthropic apophyte Urtica dioica also decreased probably due to intensive mowing. Species of the order Glechometalia like Geum urbanum, Glechoma hederaceae, Alliaria petiolata, Lapsana communis spread or stabilized their occurrence during the last 25 years. They were the basic plant group in the undergrowth of coppices and in margin vegetation. Different behaviour of forest species was observed - gradual dispersion of Ficaria verna and the distinct regress of Scrophularia nodosa. It was probably associated with mowing whose intensity increased with time. Ficaria verna is resistant to mowing while Scrophularia nodosa is not. The contribution of trampled species like Plantago major increased and stabilised during the last quarter of a century. This might be explained by increased interest in resting in the park and consequently in more intensive trampling and ground compaction during the nurturing. 
Table 1.

Changes in the frequency of occurrence of selected plant species in Skaryszewski Park between 1966 and 2004

\begin{tabular}{|c|c|c|c|}
\hline Species & 1966 & 1985 & 2004 \\
\hline Alliaria petiolata & 40 & 32.6 & 32.6 \\
\hline Arctium lappa & 15 & 8.7 & 0 \\
\hline Chaerophyllum temulentum & 0 & 13 & 2.17 \\
\hline Chelidonium majus & 70 & 23.9 & 6.5 \\
\hline Dactylis glomerata & 10 & 58.7 & 41.3 \\
\hline Festuca pratensis & 5 & 34.8 & 2.2 \\
\hline Ficaria verna & 5 & 28.3 & 34.8 \\
\hline Geum urbanum & 10 & 30.4 & 32.6 \\
\hline Glechoma hederaceae & 10 & 69.6 & 37 \\
\hline Impatiens parviflora & 35 & 4.4 & 6.5 \\
\hline Lapsana communis & 15 & 0 & 15.2 \\
\hline Plantago major & 10 & 41.3 & 32.6 \\
\hline Scrophularia nodosa & 50 & 28.3 & 10.9 \\
\hline Urtica dioica & 40 & 26.1 & 8.7 \\
\hline
\end{tabular}

In general, intensive nurturing of vegetation leads to marked changes in the structure and species composition. Total number of species decreases.

\section{CONCLUSIONS}

Studies carried out in Skaryszewski Park showed that the interdisciplinary studies allow for more comprehensive recognising the habitat potential and vegetation status of the park i.e. its natural values. Geoecological methods provide data on the status and threats of particular habitats. Geobotanical methods serve for assessing the vegetation structure, species composition and dynamics of plant communities. Presented approach should be a good basis for nurturing and for elaborating plans of park management.

\section{REFERENCES}

Bianco P.M., Fanelli G., Tescarollo P., Pignatti S., 2003, Ruderalization in a Roman Park as a result of changing management. Urban Habitats 1: 3-19.

Borowski J., Pstragowska M., Sikorski P., Orzechowski J., Mąkowski J., 2005, Wyniki badań nad fotograficzną metodą pomiaru przyrostów drzew z zastosowaniem komputerowego programu DENDRO [Investigation results of the 
photographic method of tree increment evaluation using computer program DENDRO]. Roczn. Dendrol. 53: 65-88.

Ellenberg H., Weber H., Düll R., Wirth V., Werner W., Paulissen D., 1991, Zeigerwerte der Gefässpflanzen in Mitteleuropas. Scripta Geobot. 18: 1-166.

Gilbert O.L., 1989, The Ecology of Urban Habitats. Chapman and Hall. London.

Hermy M., Cornelis J., 2000, Towards a monitoring method and a number of multifaceted and hierarchical biodiversity indicators for urban and suburban parks. Landsc. Urban Plan. 49: 149-162.

Hermy M., Cornelis J., 2004, Biodiversity relationships in urban and suburban parks in Flanders. Landsc. Urban Plan. 69: 385-401.

Jackowiak K., 2007, Funkcje ekologiczne Parku Skaryszewskiego [The ecological functions of Skaryszewski Park in Polish]. WGiSR UW, Warszawa.

Janecki J., Sawczuk E., 1995, Kompleksowa inwentaryzacja ogrodów zabytkowych metoda fitosocjologiczna [The comprehensive inventory of historical gardens using phytosociological method in Polish]. Arboretum Bolestraszyce 3: 37-45.

Jim C., Y. 1998, Soil Characteristics and Management in an Urban Park in Hong Kong. Environ. Manage. 22: 683-695.

Kin-Che L., Sai-Leung N., Wing-Chi H., Pak-Kin C., 2005, Environmental quality of urban parks and open spaces in Hong Kong. Environ. Monit. Assessment 111: 55-73.

Kobendza R., 1930, Krótki przewodnik po parku Ignacego Paderewskiego $w$ Warszawie [The short guide to Ignacy Paderewski Park in Warsaw]. Wyd. Wydziału Oświaty i Kultury Magistratu m.st. Warszawy.

Lookingbill R.T., Gardner R.H., Townsend P.A., Carter S. L., 2007, Conceptual models as hypotheses in monitoring urban landscapes. Environ. Management. 40: 171-182.

Matuszkiewicz W., 2005, Przewodnik do oznaczania zbiorowisk roślinnych Polski [A key to plant communities of Poland in Polish]. Wyd. Nauk. PWN. Warszawa.

Olenderek H., Korpetta D., Nowicki A., 1994, Możliwości wykorzystania Systemów Informacji Przestrzennej w badaniach stanu krajobrazu kulturowego na przykładzie parków zabytkowych [GIS in the research on the state of a cultural landscape on the example of historical parks in Polish]. Materiaty Konferencyjne I Krajowej Konferencji Użytkowników Arc/Info GEMINI i ERDASA. Warszawa.

Sikorski P., Wysocki 2003, Charakter zmian struktury i składu gatunkowego zadrzewień parków wiejskich na przykładzie Podkrainy Zachodniomazurskiej [Character of changes of park vegetation structure and species composition in agricultural landscape - the example of West Masurian District in Polish]. Acta Sci. Pol. Formatio Circumiectus 2: 71-86.

Szczepanowska H. (red.) 1984, Wptyw zieleni miejskiej na ksztattowanie środowiska miejskiego [Urban greenery influence on urban environment in Polish] PWN, Warszawa.

Tüxen R., 1956, Die heutige potentielle natürliche Vegetation als Gegenstand der Vegetationskartierung. Angew. Pflanzensoz. 13: 3-42.

Zipperer W. C., Zipperer C. E., 1992, Vegetation responses to changes in design and management of an urban park. Landsc. Urban Plan. 22: 1-10.

English translation: Lech Kufel 